

31 January 2002 Volume 415 Issue no 6871

\title{
Summits that matter
}

The European Commission has made good progress in gathering support for its new programme of basic and applied research. Now Europe's industries and heads of state need to fulfil promises made two years ago.

ew occasions would seem to be more remote from the everyday concerns of researchers than meetings of heads of state. Give researchers the prospect of significant funds to pursue their interests, and the autonomy to do it in the way they think is best, and you'll get their attention. Issue summit communiqués about the need to increase competitiveness and they'll nod off. But both approaches are now on the agenda in Europe, and both have the potential to boost scientists' scope for action.

No doubt one such summit, the Lisbon European Council in 2000 , had little impact on scientists at the time. Certainly, it has made precious little difference to them since, even though it was intended to mark the start of a golden age for science and innovation in the European Union (EU). Within a decade, the heads of state asserted, the EU would become the most dynamic, competitive, sustainable, knowledge-based economy in the world, enjoying full employment and social cohesion. Massive investment in science and education would ensure the realization of this vision.

Two years later, any euphoria has vanished. Key deliverables, such as a cheap EU patent, are still yet to materialize, despite much discussion. Negotiations over the planned European satellite navigation system Galileo, a major public-industry technology investment, are bogged down. The 'European Research Area', a concept pushed by research commissioner Philippe Busquin, suffers from a lack of support from some member states and - perhaps as a consequence - a lack of substance. Insiders at the European Commission openly speak of a "delivery gap" which threatens its credibility. And industry's expenditure on research and development itself is too low: only $55 \%$ of R\&D in the EU is funded by industry, compared with $72 \%$ in Japan and $67 \%$ in the United States.

\section{Overcoming obstacles}

But things are looking up. Supported by the zealous Spanish presidency of the EU, the commission is now working hard to get back on track. Ministers for industry and for research from 15 member states will meet next week in Spain for the first time, to discuss obstades to the Lisbon objectives. Breakthroughs are unlikely, but this is nonetheless a long-overdue initiative.

The commission's 2003-06 Framework programme for research, now well on its way to final approval to the tune of 16.2 billion euros (US\$14 billion), will strongly support industrial participation in large 'integrated' projects (see http://europa.eu.int/comm/research/ $\mathrm{nfp} . \mathrm{html}$ ). Such projects are yet to be defined by the research community and look daunting to manage, but are of sufficient scale and scope to make an impact on both fundamental and applied research, and are already attracting interest. And at the European Council in Barcelona in March, the commission will urge the heads of the member states to set a target of $3 \%$ of gross domestic product for the overall level of public and private spending on research by 2010 , two-thirds of which would be contributed by industry - double their presentlevel.

Such a goal cannot be achieved by government or commission fiat. Nor can it be expected to happen spontaneously: Finland and
Sweden, which already surpass the $3 \%$ target, hardly serve as a model for large and highly diversified economies such as those of Germany, Italy, France or Britain. Thus, one must move step-by-step to create an economic and regulatory environment that is more friendly to companies of all sizes willing to invest in research, and to encourage some multinational companies to shift the balance of their R\&D spending towards labs in Europe.

\section{Action plan}

The European Commission estimates that the market potential of the biotechnology industry in Europe will be 100 billion euros by 2005 . But the exploitation of this potential is sluggish. Accordingly, at the Barcelona summit, the commission will present an action plan for the life sciences, which it published last week, induding the development of a bioinformatics infrastructure, regulatory harmonization, and centralized authorization procedures for the environmental release of genetically engineered organisms (GMOs).

The plan also reflects the commission's need to address the tensions between the economic benefits of biotechnology and the concerns of Europe's citizens, in particular with regard to GMOs, whose commercial release in Europe is currently under a moratorium. It calls for broad publicdebate, encourages regular stakeholder forums and promises the establishment of a publicly accessible 'molecular register' of occurrences of deliberate genetic modification. With regards to ethical controversies in biomedical research, it suggests networking of national and local ethics bodies and encourages self-regulatory initiatives in the scientific community and industry. At thesame time, it is pursuing new pro-pharmaceutical legislation, such as accelerated approval procedures and one-year conditional authorization.

Such regulatory changes will require determined political leadership. From a scientist's point of view, any attempt to increase research spending and temper regulatory burdens is to be welcomed. So, too, is another key aspect of the new Framework programme: large-scale

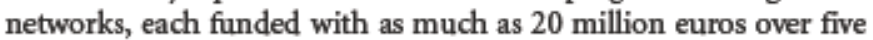
or more years, with money that is not earmarked and therefore provides autonomy for the collaborators in their ability to develop new facilities or new centres of excellence.

Underlying these plans is a determination by Philippe Busquin to move away from non-scientific agendas and to foster world-beating collaborations. Gone from his plans is "cohesion", wherebylaboratories from less-well-developed countries are included in collaborations thanks to affirmative action. There is also a stronger move than hitherto to support the pursuit of scientific knowledge for its own sake, as well as for its application.

That shift, combined with giving researchers more independence and, as one commission insider puts it, an ambition to distribute funds like hailstones rather than fine mist, should all be good news to outstanding researchers able to make use of the opportunities. But if the heads of state don't also provide high-level backing, both for the commission and within their own countries, Europe's technological and, in the longer term, scientific competitiveness seem certain to weaken. 